\title{
Peningkatan Hasil Belajar Siswa Pada Pembelajaran Tematik Terpadu Tema 8 Menggunakan Model Project Based Learning (PjBL) Di Kelas V SD Negeri 20 Indarung Kota Padang
}

\author{
${ }^{1}$ Zulfa Winanda, ${ }^{2}$ Melva Zainil, ${ }^{3}$ Delismita Pusra \\ 1,2Pendidikan Profesi Guru Pra Jabatan Program Studi Pendidikan Guru Sekolah \\ Dasar, Universitas Negeri Padang \\ ${ }^{3}$ SD Negeri 20 Indarung \\ e-mail: ${ }^{1}$ zulfawinanda21@gmail.com, ${ }^{2}$ melvazainil@fip.unp.ac.id, \\ 32delismitapusra70@gmail.com
}

\begin{abstract}
Abstrak
Penelitian ini dilatarbelakangi hasil belajar siswa kelas V SD Negeri 20 Indarung Kota Padang masih rendah. Hal ini disebabkan oleh guru belum menggunakan model pembelajaran yang sesuai untuk hasil belajar peserta siswa. Tujuan dari penelitian ini adalah mendeskripsikan penerapan model pembelajaran Project Based Learning (PjBL) untuk meningkatkan hasil belajar di kelas V SDN 20 Indarung Kota Padang. Jenis penelitian ini adalah Penelitian Tindakan Kelas menggunakan pendekatan kualitatif dan kuantitatif. Prosedur penelitian meliputi perencanaan, pelaksanaan, pengamatan, dan refleksi. Data penelitian berupa hasil pengamatan dan tindakan serta hasil tes. Sumber data adalah proses dan hasil pelaksanaan pembelajaran dengan menggunakan model PjBL pada materi urutan peristiwa atau tindakan yang terdapat pada teks nonfiksi dan siklus air dan dampaknya pada peristiwa di bumi serta kelangsungan makhluk hidup. Penelitian ini dilaksanakan pada Semester II Tahun Ajaran 2020/2021. Subjek penelitian adalah guru selaku observer, peneliti selaku praktisi, dan siswa kelas $\mathrm{V}$ sebanyak 20 orang. Hasil penelitian menunjukkan peningkatan rata-rata hasil belajar siswa pada siklus । $78,46 \%$ menjadi $85,53 \%$ pada siklus II. Hasil penilaian proyek siswa menunjukkan peningkatan ratarata pada siklus I $69,42 \%$ menjadi $83,18 \%$ pada siklus II. Hasil pengamatan RPP pada siklus I dari $83,90 \%$ menjadi $92,9 \%$ pada siklus II. Hasil pengamatan aspek guru dan siswa pada siklus I adalah $78,1 \%$ menjadi $93,8 \%$ pada siklus II. Dapat disimpulkan bahwa, model PjBL dapat meningkatkan kemampuan hasil belajar di kelas IV SD Negeri 20 Indarung Kota Padang.
\end{abstract}

Kata kunci: project based learning, hasil belajar

\begin{abstract}
The background of this research is that the learning outcomes of fifth grade students of SD Negeri 20 Indarung, Padang City are still low. This is because the teacher has not used an appropriate learning model for student learning outcomes. The purpose of this study is to describe the application of thelearning model Project Based Learning (PjBL)to improve
\end{abstract}


learning outcomes in class V at SDN 20 Indarung, Padang City. This type of research is Classroom Action Research using qualitative and quantitative approaches. The research procedure includes planning, implementation, observation, and reflection. Research data in the form of observations and actions as well as test results. Sources of data are the process and results of implementing learning using the $\mathrm{PjBL}$ model on the material for the sequence of events or actions contained in nonfiction texts and the water cycle and their impact on events on earth and the survival of living things. This research was conducted in Semester II of the 2020/2021 Academic Year. The research subjects were teachers as observers, researchers as practitioners, and 20 class $V$ students. The results showed an increase in the average student learning outcomes in the first cycle from $78.46 \%$ to $85.53 \%$ in the second cycle. The results of the student project assessment showed an average increase in the first cycle of $69.42 \%$ to $83.18 \%$ in the second cycle. The results of the RPP observations in the first cycle from $83.90 \%$ to $92.9 \%$ in the second cycle. The results of observations of teacher and student aspects in the first cycle were $78.1 \%$ to $93.8 \%$ in the second cycle. It can be concluded that the PjBL model can improve the ability of learning outcomes in grade IV SD Negeri 20 Indarung, Padang City.

Keywords : project based learning, learning outcomes

\section{PENDAHULUAN}

Pembelajaran tematik terpadu memiliki beberapa tahap pelaksanaan. Menurut Majid (2014) dalam pelaksanaan pembelajaran tematik terpadu perlu dilakukan beberapa hal yang meliputi tahap perencanaan yang mencangkup kegiatan pemetaan kompetensi dasar, pengembangan jaringan tema, pengembangan silabus dan penyusunan rencana pelaksanaan pembelajaran. Hal ini sangat memberikan kontribusi dalam peningkatan hasil belajar siswa.

Dalam peningkatan hasil belajar siswa perlu adanya suatu perencanaan yang matang sebelum pembelajaran itu dilaksanakan. Perencanaan ini bertujuan agar tujuan pembelajaran dapat tercapai sesuai kompetensi dan indikator pembelajaran. Adapun Sugyar (dalam Sumantri, Muhammad syarif , 2015) mengemukakan tahapan yang harus ditempuh di dalam pelaksanaan pembelajaran yakni tahap permulaan, tahap pembelajaran serta tahap evaluasi dan tindak lanjut.

Tahap permulaan pada hakikatnya bertujuan untuk mengungkapkan kembali tanggapan siswa terhadap bahan yang telah diterimanya serta menumbuhkan semangat di dalam pelaksanaan pembelajaran pada hari itu. Adapun pada tahap pembelajaran merupakan tahap inti dari suatu pembelajaran dimana guru memberikan bahan atau materi pelajaran yang telah disusun sebelumnya. Sedangkan pada tahap evaluasi dan tindak lanjut bertujuan untuk mengetahui tingkat keberhasilan siswa pada suatu pembelajaran.

Berdasarkan observasi yang peneliti lakukan di kelas V SDN 20 Indarung, Kota Padang tanggal 11, 12, dan 13 Januari 2021 saat berlangsung Tema 5 Ekosistem Subtema 1 Komponen Ekosistem pada materi menemukan pokok pikiran dalam teks nonfiksi dan hubungan antar komponen ekosistem dan jaring-jaring makanan di lingkungan sekitar. 
Selama proses pembelajaran berlangsung, peneliti menemukan beberapa hal yang belum optimal seperti penerapan pembelajaran tematik terpadu yang semestinya, diantaranya : 1) guru belum mengoptimalkan penggunaan RPP; 2) pembelajaran belum memberikan pengalaman langsung kepada siswa, terlihat dari siswa belum membuat karya tentang konsep jaring-jaring makanan dalam suatu ekosistem; 3) masih terlihatnya pemisahan antar mata pelajaran sehingga bisa dikatakan tematik terpadu yang dilaksanakan guru belum sesuai dengan yang seharusnya; 4) guru belum terlihat menerapkan model pembelajaran yang berbasis proyek dan kurang memberikan stimulasi atau rangsangan kepada siswa saat pembelajaran.

Dari berbagai masalah tersebut, tentu akan berakibat pada proses pembelajaran dan siswa itu sendiri. Akibat yang ditimbulkan, diantaranya : 1) pembelajaran berlangsung dengan kurang terstruktur; 2) siswa menjadi pasif dan merasa bosan dengan materi yang disajikan guru ; 3) siswa mengetahui mata pelajaran yang sedang dipelajari, padahal dalam tematik terpadu siswa seharusnya belajar secara terpadu dengan menggunakan tema; 4) pembelajaran terkesan monoton dan siswa menjadi malas dalam belajar. Sehingga pada akhirnya hal ini berdampak pada rendahnya hasil belajar siswa. Dapat ditunjukkan pada Penilaian Harian (PH) 1 Tema 5 Subtema 1 siswa kelas V SD Negeri 20 Indarung Tahun Ajaran 2020/2021.

Pada tabel 1 terlihat bahwa pencapaian hasil belajar siswa banyak yang belum memenuhi standar ketuntasan, masih ada siswa yang mendapatkan nilai dibawah KKM yang ditetapkan oleh guru kelas yaitu 75 . Untuk mengatasi permasalahan di atas guru dapat memilih model pembelajaran yang tepat. Salah satu model pembelajaran yang dapat digunakan untuk meningkatkan hasil belajar siswa dalam pembelajaran tematik terpadu adalah model Project Based Learning (PjBL). Menurut Tracy (2012) bahwa "Innovative models of schooling such as those described as project-based or design-based learning". Artinya model inovatif yang dapat diterapkan di sekolah yaitu model pembelajaran berbasis proyek atau desain.

Dalam pembelajaran tematik terpadu pada kurikulum 2013 diharapkan menggunakan model pembelajaran. Model pembelajaran Project Based Learning merupakan salah satu model pembelajaran yang bisa diterapkan dalam pembelajaran tematik terpadu. Selain itu, model Project Based Learning juga model pembelajaran yang berpusat pada siswa (students center). Model Project Based Learning menurut Faisal (2014) merupakan suatu model pembelajaran inovatif yang menekankan belajar secara kontekstual melalui kegiatankegiatan yang kompleks. Model pembelajaran yang demikian membuat pembelajaran yang melibatkan siswa dalam investigasi dan kegiatan tugas-tugas bermakna lain, yang akan menjadikan pembelajaran lebih bermakna dan lama diingat oleh siswa karena mereka sendirilah yang menemukan atau mengasimilasikan sendiri konsep, prinsipnya melalui kegiatan-kegiatan yang kompleks dengan menghasilkan produk nyata diakhir pembelajaran.

Pada buku guru tema 8 , beberapa materi dianjurkan untuk menggunakan model $\mathrm{PjBL}$ dalam pembelajaran salah satunya materi peristiwa atau tindakan yang terdapat pada teks nonfiksi dan siklus air. Model PjBL adalah model pembelajaran yang memberikan kesempatan kepada guru untuk mengelola pembelajaran di kelas dengan melibatkan kerja proyek yang memuat tugas-tugas yang kompleks. Dengan proyek yang dikerjakan siswa 
sebagai langkah awal dalam mengumpulkan dan mengintegrasikan pengetahuan baru berdasarkan pengalamannya dalam beraktivitas secara nyata dan menuntut siswa untuk melakukan kegiatan merancang, memecahkan masalah, membuat keputusan, melakukan kegiatan investigasi, serta memberikan kesempatan siswa untuk bekerja secara mandiri maupun kelompok. Hasil akhir dari kerja proyek adalah suatu produk baik laporan tertulis atau lisan, presentasi atau rekomendasi (Maudi, 2016).

Tabel 1. Rekapitulasi Hasil Penilaian Harian Tema 5 Subtema 1

\begin{tabular}{|c|c|c|c|c|c|c|c|c|c|c|}
\hline \multirow[b]{2}{*}{ No } & \multirow[b]{2}{*}{ Nama } & \multicolumn{2}{|c|}{$\begin{array}{l}\text { Bahasa } \\
\text { Indonesia }\end{array}$} & \multicolumn{2}{|c|}{ IPA } & \multirow{2}{*}{ Jumlah } & \multirow{2}{*}{$\begin{array}{l}\text { Rata- } \\
\text { Rata }\end{array}$} & \multirow{2}{*}{$\begin{array}{c}\text { Klasifi } \\
\text { kasi }\end{array}$} & \multicolumn{2}{|c|}{ Ketuntasan } \\
\hline & & $\begin{array}{c}\mathrm{KK} \\
\mathrm{M}\end{array}$ & Nilai & $\begin{array}{c}\mathrm{KK} \\
\mathbf{M}\end{array}$ & Nilai & & & & Tuntas & $\begin{array}{c}\text { Tidak } \\
\text { Tuntas }\end{array}$ \\
\hline 1 & AR & 75 & 52 & 75 & 60 & 112 & 56 & $\mathrm{~K}$ & & $\sqrt{ }$ \\
\hline 2 & AS & 75 & 50 & 75 & 40 & 90 & 45 & $\mathrm{~K}$ & & $\sqrt{ }$ \\
\hline 3 & ARS & 75 & 80 & 75 & 60 & 140 & 70 & $C$ & & $\sqrt{ }$ \\
\hline 4 & BMN & 75 & 40 & 75 & 60 & 100 & 50 & $\mathrm{~K}$ & & $\sqrt{ }$ \\
\hline 5 & $\mathrm{FK}$ & 75 & 60 & 75 & 60 & 120 & 60 & $\mathrm{~K}$ & & $\sqrt{ }$ \\
\hline 6 & FAF & 75 & 80 & 75 & 100 & 180 & 90 & $A$ & $\sqrt{ }$ & \\
\hline 7 & HR & 75 & 75 & 75 & 70 & 145 & 72,5 & C & & $\sqrt{ }$ \\
\hline 8 & $\mathrm{KHK}$ & 75 & 55 & 75 & 80 & 135 & 67,5 & $C$ & & $\sqrt{ }$ \\
\hline 9 & KNA & 75 & 80 & 75 & 80 & 160 & 80 & $B$ & $\sqrt{ }$ & \\
\hline 10 & LPS & 75 & 60 & 75 & 70 & 130 & 65 & $\mathrm{~K}$ & & $\sqrt{ }$ \\
\hline 11 & MAR & 75 & 40 & 75 & 60 & 100 & 50 & $\mathrm{~K}$ & & $\sqrt{ }$ \\
\hline 12 & MAL & 75 & 80 & 75 & 40 & 120 & 60 & $\mathrm{~K}$ & & $\sqrt{ }$ \\
\hline 13 & NSS & 75 & 80 & 75 & 80 & 160 & 80 & B & $\sqrt{ }$ & \\
\hline 14 & QAN & 75 & 80 & 75 & 100 & 180 & 90 & A & $\sqrt{ }$ & \\
\hline 15 & RSP & 75 & 80 & 75 & 80 & 160 & 80 & B & $\sqrt{ }$ & \\
\hline 16 & $\mathrm{RHH}$ & 75 & 60 & 75 & 60 & 120 & 60 & $\mathrm{~K}$ & & $\sqrt{ }$ \\
\hline 17 & RF & 75 & 80 & 75 & 100 & 180 & 90 & $A$ & $\sqrt{ }$ & \\
\hline 18 & SMM & 75 & 60 & 75 & 60 & 120 & 60 & $\mathrm{~K}$ & & $\sqrt{ }$ \\
\hline 19 & $\mathrm{ZF}$ & 75 & 40 & 75 & 80 & 120 & 60 & $\mathrm{~K}$ & & $\sqrt{ }$ \\
\hline 20 & ZSD & 75 & 80 & 75 & 100 & 180 & 90 & $\mathrm{~K}$ & $\sqrt{ }$ & \\
\hline \multicolumn{2}{|c|}{ Jumlah } & & 1312 & & 1440 & 2752 & 1376 & & 7 & 13 \\
\hline \multicolumn{2}{|c|}{ Rata-Rata } & & 65,6 & & 72 & & 68,8 & & & \\
\hline \multicolumn{2}{|c|}{ Klasifikasi } & & & & & & $\mathrm{C}$ & & & \\
\hline \multicolumn{2}{|c|}{ Persentase } & & & & & & & & $35 \%$ & $65 \%$ \\
\hline
\end{tabular}


Dengan menerapkan pembelajaran tematik terpadu menggunakan model Project Based Learning (PjBL) diharapkan dapat memberikan pengalaman belajar langsung sehingga membuat siswa lebih aktif, dan berfikir kritis. Hal ini sejalan dengan pendapat Solomon (dalam Kizkapan, 2016) menyatakan bahwa "PjBL contributes to students academic achievement by creating a more equal learning environment". PjBL berkontribusi prestasi akademik siswa dengan menciptakan lingkungan belajar yang lebih setara. Jadi, dengan menggunakan model PjBL ini dapat membuat siswa menjadi lebih aktif, memberikan pengalaman langsung dengan pembelajaran berbasis proyek, dan mampu mengembangkan kemampuan berfikir kritis sehingga dapat meningkatkan hasil belajar siswa.

\section{Hasil Belajar}

Belajar adalah proses yang dilakukan untuk mencapai tujuan belajar berupa hasil belajar. Hasil belajar menjadi salah satu indikator tercapai atau tidaknya suatu proses pembelajaran. Menurut Oemar (2008) hasil belajar adalah tingkah laku yang timbul, misalnya dari tidak tahu menjadi tahu, timbulnya pertanyaan baru, perubahan dari setiap kebiasaan, keterampilan, kesanggupan dalam menghargai. Sedangkan menurut Sudjana (2011) hasil belajar yaitu suatu perubahan yang terjadi pada individu yang belajar, bukan hanya perubahan mengenai pengetahuan, tetapi juga untuk membentuk kecakapan, kebiasaan dan penghargaan dalam diri sesorang yang belajar.

Dimyati (2009) berpendapat bahwa hasil belajar merupakan hasil yang ditunjukkan dari suatu interaksi tindak belajar dan biasanya ditunjukkan dengan nilai tes yang diberikan guru. Adapun Hamalik (2009) mengemukakan bahwa hasil belajar menunjukkan kepada prestasi belajar, sedangkan prestasi belajar merupakan indikator adanya derajat perubahan tingkah laku siswa.

Dari beberapa pendapat ahli di atas, dapat disimpulkan bahwa hasil belajar adalah suatu perubahan yang terjadi pada individu, tidak hanya pada perubahan tingkah laku dan pengetahuan, namun juga untuk membentuk kecakapan, kebiasaan dan penghargaan dalam diri seseorang yang belajar yang biasanya dibuktikan dengan nilai tes dari guru.

Hasil belajar siswa terutama pada kurikulum 2013 terbagi menjadi tiga ranah, yakni Sikap, Pengetahuan, serta Keterampilan. Proses penilaian ketiga ranah tersebut harus dilakukan secara berimbang.

Widoyoko (2016:23) mengungkapkan hasil belajar siswa yang dinilai mencakup aspek atau ranah sikap, pengetahuan, dan keterampilan. Penjelasan mengenai ketiga aspek hasil belajar sebagai berikut: 1) Sikap. Pada kurikulum 2013 aspek sikap terdiri dari sikap spiritual dan sikap sosial. Sikap spiritual terdapat pada Kompetensi Inti 1 (KI-1) Menerima, menjalankan, dan menghargai ajaran agama yang dianutnya. Sedangkan sikap sosial terdapat pada Kompetensi Inti 2 (KI-2) Menunjukkan perilaku jujur, disiplin, santun, percaya diri, peduli, dan bertanggung jawab dalam berinteraksi dengan keluarga, teman, guru, tetangga, dan negara. 2) Pengetahuan. Ranah pengetahuan sering disebut sebagai ranah kognitif. Ranah ini berkenaan dengan kemampuan dalam berpikir. Hal ini sejalan dengan pendapat Ariyana, dkk. (2018) yang mengatakan bahwa ranah kognitif berkenaan dengan kemampuan dalam berpikir, kompetensi dalam mengembangkan pengetahuan, pengenalan, pemahaman, konseptualisasi, penentuan dan penalaran. 3) Keterampilan. 
Keterampilan berkaitan dengan tindakan atau kemampuan melakukan sesuatu. Aspek keterampilan atau Psikomotor menurut Bloom (dalam Sudjana, 2009) berkaitan dengan hasil belajar keterampilan dan kemampuan bertindak. Sedangkan menurut Rusman (2015) mengatakan bahwa aspek keterampilan dapat di lihat dengan cara unjuk kerja atau praktik, proyek, dan portofolio.

\section{Project Based Learning}

Salah satu model pembelajaran yang digunakan dalam implementasi kurikulum 2013 adalah pembelajaran berbasis proyek (Project Based Learning). Trianto (2014) mengatakan bahwa Project Based Learning merupakan pembelajaran inovatif yang berpusat pada siswa (student centered) dan menempatkan guru sebagai motivator dan fasilitator, dimana siswa diberi peluang bekerja secara otonom mengkonstruksi belajarnya. Kemudian Daryanto (2014) mengatakan bahwa Pembelajaran berbasis proyek (Project Based Learning) adalah model pembelajaran yang menggunakan proyek atau kegiatan sebagai media.

Pembelajaran berbasis proyek adalah model pembelajaran dimana guru mengelola pembelajaran di kelas dengan melibatkan kerja proyek yang memuat tugas-tugas yang kompleks berdasarkan permasalahan (Project) sebagai langkah awal dalam mengumpulkan dan mengintegrasikan pengetahuan baru berdasarkan pengalamannya dalam beraktivitas secara nyata dan menuntut siswa untuk melakukan kegiatan merancang, memecahkan masalah, membuat keputusan, melakukan kegiatan investigasi, serta memberikan kesempatan siswa untuk bekerja secara mandiri maupun kelompok. Hasil akhir dari kerja proyek tersebut adalah suatu produk yang antara lain berupa laporan tertulis atau lisan, presentasi atau rekomendasi (Maudi, 2016).

Pembelajaran berbasis proyek adalah model pembelajaran yang sistematis, melibatkan siswa dalam mempelajari pengetahuan dan keterampilan melalui penyelidikan yang panjang dan terstruktur proses dengan pertanyaan-pertanyaan otentik dan kompleks dan tugas-tugas produk yang dirancang dengan cermat. Project-Based Learning is a systematic learning model, involving learners in learning knowledge and skills through a long, structured inquiry process with authentic and complex questions and carefully designed product tasks (Yamin, dkk, 2017).

Menurut Turgut (2008) PjBL merupakan pembelajaran yang terdiri dari proyek yang mengintegrasikan ilmu pengetahuan, teknologi, masyarakat, sejarah, matematika, politik, dan kesempatan diskusi produktif untuk siswa, mendorong penyelidikan siswa yang diarahkan pada masalah dunia nyata, dan memberikan mereka semangat belajar dan pengajaran efektif.

Berdasarkan pendapat di atas dapat disimpulkan bahwa model PjBL merupakan model pembelajaran inovatif yang menekankan belajar melalui kegiatan-kegiatan yang kompleks dengan pembelajaran berpusat pada siswa yang menghasilkan suatu produk.

Berdasarkan teori di atas, maka peneliti menggunakan teori langkah-langkah PjBL menurut Hosnan (2014) adalah 1) Penentuan proyek; 2)Perancangan langkah-langkah penyelesaian proyek; 3) Penyusunan jadwal pelaksanaan proyek; 4) Penyelesaian proyek dengan fasilitas dan monitoring guru; 5) Penyusunan laporan dan presentasi atau publikasi hasil proyek; 6) Evaluasi proses dan hasil proyek". Dapat dijabarkan sebagai berikut: 1) 
Penentuan proyek. Siswa menentukan tema atau topik proyek berdasarkan tugas proyek yang diberikan oleh guru baik secara kelompok ataupun mandiri. 2) Perancangan langkahlangkah penyelesaian proyek. Siswa merancang langkah-langkah kegiatan penyelesaian proyek, berisi aturan main dalam pelaksanaan tugas proyek, pemilihan aktivitas, perencanaan sumber, bahan, alat, dan kerja sama anataranggota kelompok. 3) Penyusunan jadwal pelaksanaan proyek. Siswa dengan guru melakukan penjadwalan kegiatan yang telah dirancang, berapa lama proyek itu harus diselesaikan. 4) Penyelesaian proyek dengan fasilitas dan monitoring guru. Siswa mengimplementasikan rancangan proyek yang telah dibuat. Guru memonitor aktivitas siswa dalam melakukan tugas proyek, mulai dari proses hingga penyelesaian proyek. 5) Penyusunan laporan dan presentasi/publik hasil proyek. Hasil proyek dalam bentuk produk, baik berupa produk karya tulis, karya seni, atau karya teknologi atau prakarya dipresentasikan atau dipublikasikan kepada siswa yang lain dan guru. 6) Evaluasi proses dan hasil proyek. Guru dan siswa pada akhir proses pembelajaran melakukan refleksi terhadap aktivitas dan hasil tugas proyek.

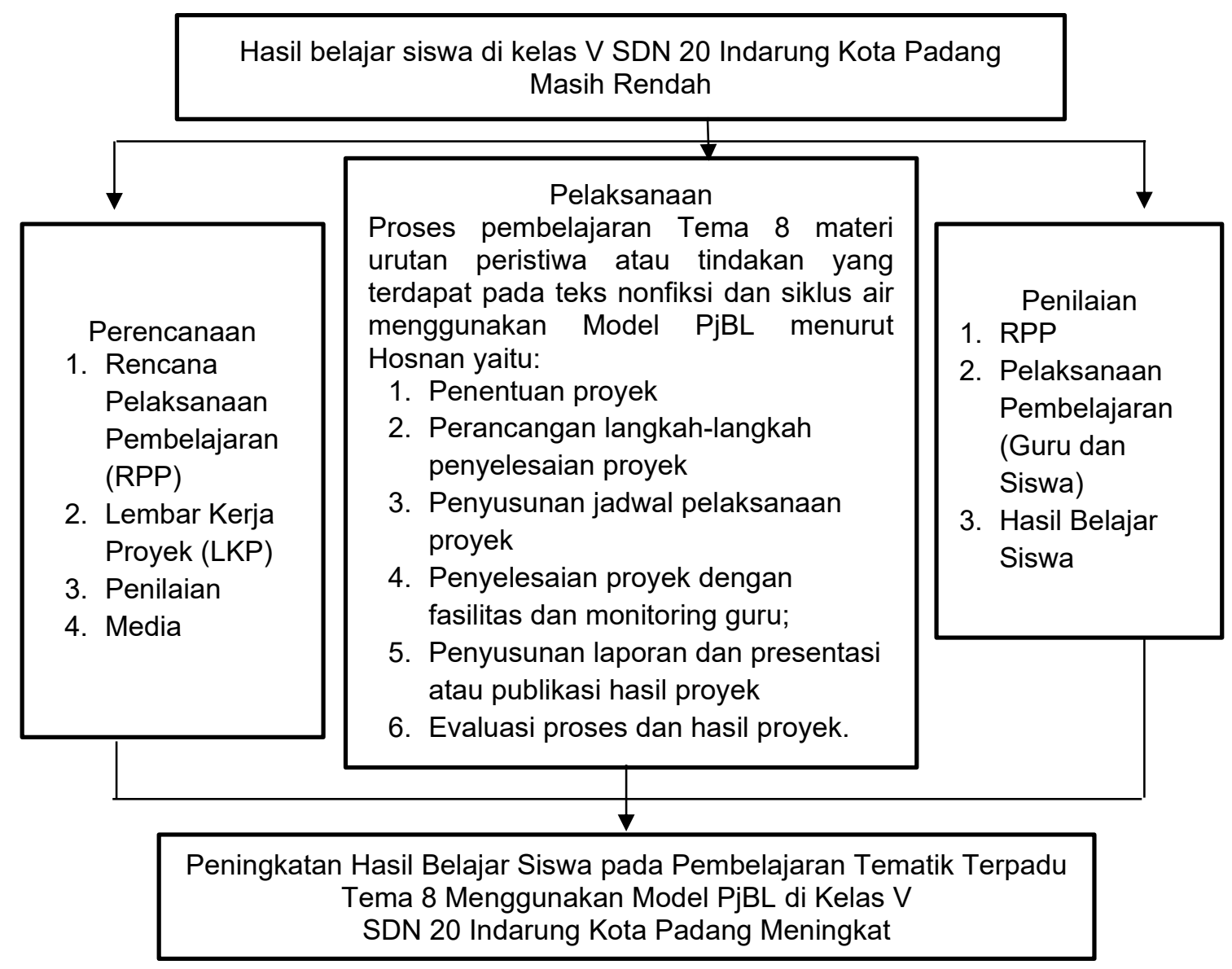

Bagan 1. Kerangka Teori 


\section{METODE}

Dalam penelitian ini, peneliti menggunakan penelitian pendekatan kualitatif dan kuantitatif. Pendekatan kualitatif adalah pendekatan yang menghasilkan data deskriptif berupa kata-kata tertulis atau lisan dari orang-orang dan prilaku yang dapat diamati (Bog dan dan Taylor dalam Basrowi, 2008). Pendekatan kuantitatif adalah pendekatan yang bermula dari studi tentang ilmu-ilmu alam berupa kajian pseudo-kuantitaf yang mengharuskan semua kajian penelitian diukur dengan angka-angka kuantitatif secara ontologis dan harus diletakkan pada tatanan realisme (Basrowi, 2008).

Jenis penelitian yang dilaksanakan adalah penelitian tindakan kelas (PTK) atau Action Research Class. Penelitian tindakan kelas adalah penelitian yang dilaksanakan oleh guru dalam kelas untuk perbaikkan pembelajaran. Kunandar (2010) menyatakan bahwa : Penelitian Tindakan Kelas adalah sebuah bentuk kegiatan refleksi diri yang dilakukan oleh para pelaku pendidikan dalam suatu situasi kependidikan untuk memperbaiki rasionalitas dan keadilan tentang: (a) praktik-praktik kependidikan mereka, (b) pemahaman mereka tentang praktik-praktik tersebut, dan (c) situasi di mana praktik-praktik tersebut dilaksanakan. Menurut Uno, dkk (2012) bahwa "penelitian tindakan kelas adalah penelitian yang dilakukan oleh guru didalam kelasnya sendiri melalui refleksi diri dengan tujuan untuk memperbaiki kinerjanya sebagai guru sehingga proses pembelajaran dapat berjalan dengan baik dan hasil belajar siswa meningkat.

Jadi dapat disimpulkan bahwa penelitian tindakan kelas adalah penelitian yang dilakukan dalam tindakan di dalam kelas melalui refleksi diri untuk memperbaiki kinerja sehingga terjadi peningkatan hasil belajar dan proses pembelajaran dapat berjalan dengan baik, serta tercapainya tujuan pembelajaran yang diharapkan. Jika terdapat peningkatan hasil belajar dan proses pembelajaran, maka perlakuan disebut memiliki peningkatan yang signifikan. 
Studi pendahuluan berdasarkan observasi latar SD, guru, dan proses pembelajaran dalam hasil belajar siswa di Kelas V SDN 20 Indarung masih rendah

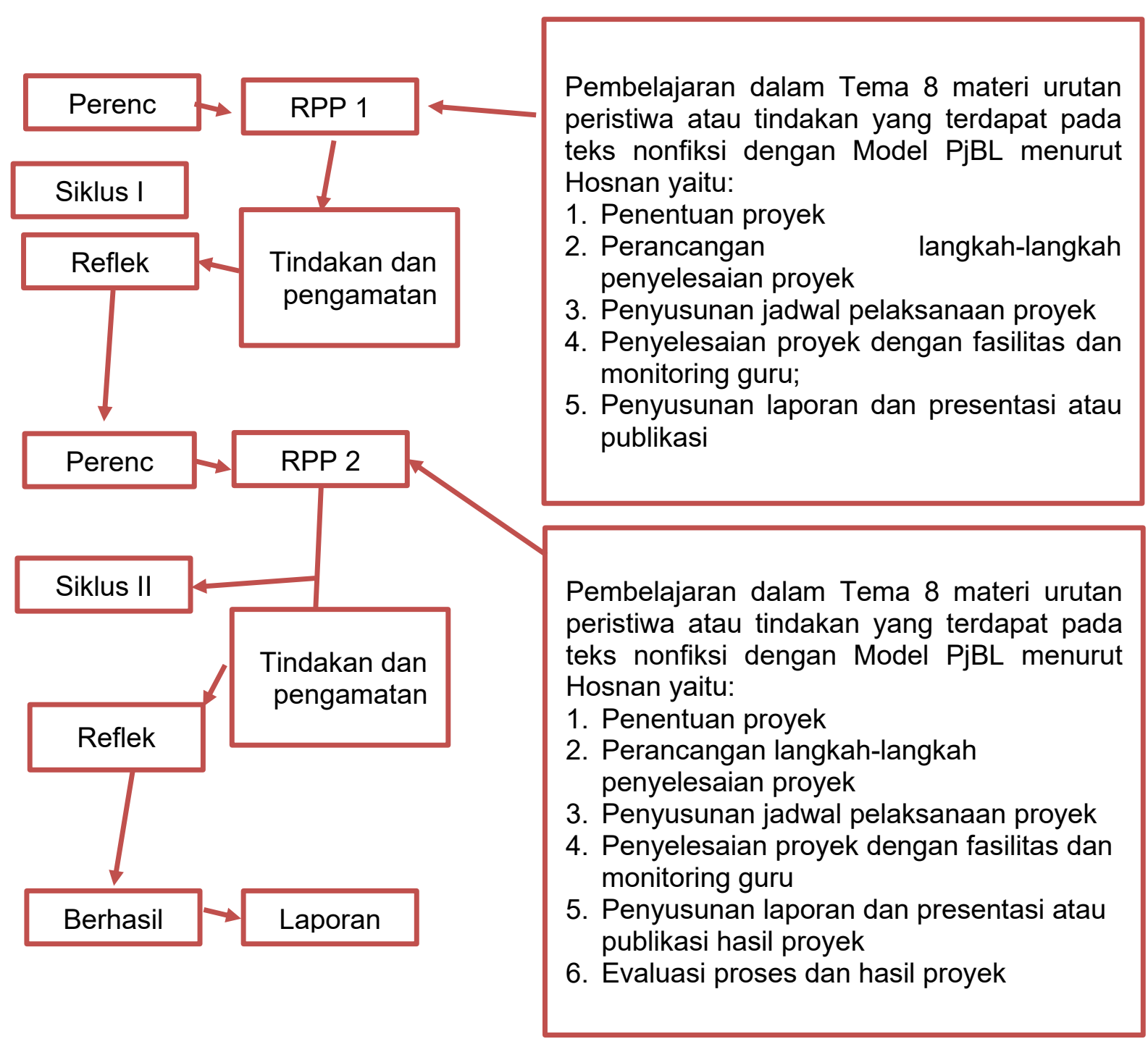

\section{Bagan 2. Alur Penelitian Tindakan Kelas}

\section{HASIL DAN PEMBAHASAN}

Dari hasil penelitian yang dilakukan di SD Negeri 20 Indarung Kota Padang, diperoleh hasil pengamatan RPP, pelaksanaan pembelajaran (aspek guru, dan aspek siswa), dan hasil belajar siklus I dan siklus II berikut. 


\section{Penelitian Siklus I}

Pada siklus I terdiri dari dua kali pertemuan, yaitu siklus I pertemuan I dilaksanakan pada tanggal 10 Maret 2021 pada pukul 07.30 - 10.30 WIB. Siklus I pertemuan II I dilaksanakan pada tanggal 17 Maret 2021 pada pukul $07.30-10.30$ WIB.

1. Perencanaan
a. RPP
b. LKP
c. Lembar Evaluasi
d. Kunci jawaban lembar evaluasi
e. Instrumen Penilaian RPP
f. Lembar Pengamatan Aktivitas Guru
g. Lembar Pengamatan aktivitas Siswa

2. Pelaksanaan

Pelaksanaan pembelajaran pada siklus I pertemuan I dan pertemuan II dengan model Project Based Learning (PjBL) dilaksanakan dikelas V SDN 20 Indarung. Pertemuan pertama dilaksanakan pada hari Rabu tanggal 10 Maret 2021, dan 17 Maret 2021 pada pukul 07.30 sampai 10.30 WIB. Siswa yang hadir pada pertemuan ini berjumlah 20 orang. Pada saat pelaksanaan, peneliti berperan sebagai praktisi (guru) dan guru kelas $\mathrm{V}$ sebagai observer yang mengamati jalannya pembelajaran tematik terpadu Tema 8 Subtema 1 Pembelajaran 1 pada pertemuan I, dan pembelajaran tematik terpadu Tema 8 Subtema 2 Pembelajaran 1 pada pertemuan II dengan model Problem Based Learning (PBL). Pelaksanaan terdiri dari 3 kegiatan meliputi kegiatan pendahuluan, inti, dan penutup.

3. Pelaksanaan
a. RPP
b. Pelaksanaan pembelajaran (Kegiatan guru \& Kegiatan Siswa).

4. Refleksi

Pelaksanaan siklus I pertemuan I ini masih belum terlaksana dengan baik. Hal itu ditandai dengan masih terdapatnya kekurangan dalam aspek perencanaan, pelaksanaan, dan hasil belajar.

\section{Rekapitulasi Hasil Pengamatan Siklus I}

\begin{tabular}{|c|c|c|c|c|c|c|}
\hline \multirow{2}{*}{\multicolumn{2}{|c|}{ Hasil Pengamatan }} & \multicolumn{5}{|c|}{ Siklus I } \\
\hline & & \multirow{2}{*}{$\begin{array}{l}\text { Pertemuan I } \\
\text { 82,1\% }\end{array}$} & \multirow{2}{*}{$\begin{array}{l}\text { Pertemuan II } \\
\text { 85,71\% }\end{array}$} & \multirow{2}{*}{$\begin{array}{l}\text { Jumlah } \\
167,81 \%\end{array}$} & \multirow{2}{*}{$\begin{array}{l}\text { Rata-rata } \\
83,905 \%\end{array}$} & \multirow{2}{*}{$\begin{array}{c}\text { Kualifik } \\
\text { asi } \\
\text { B }\end{array}$} \\
\hline $\begin{array}{c}\text { Rencana } \\
\text { Pelaksanaan } \\
\text { Pembelajaran }\end{array}$ & RPP & & & & & \\
\hline \multirow[t]{2}{*}{$\begin{array}{l}\text { Pelaksanaan } \\
\text { Pembelajaran }\end{array}$} & $\begin{array}{c}\text { Aspek } \\
\text { Guru }\end{array}$ & $71,9 \%$ & $84,3 \%$ & $156,2 \%$ & $78,1 \%$ & B \\
\hline & $\begin{array}{l}\text { Aspek } \\
\text { Siswa }\end{array}$ & $71,9 \%$ & $84,3 \%$ & $156,2 \%$ & $78,1 \%$ & B \\
\hline
\end{tabular}




\section{Rekapitulasi Hasil Belajar Siklus I}

\begin{tabular}{c|c|c|c|c|c|} 
Hasil Pengamatan & \multicolumn{5}{|c|}{ Siklus I } \\
Hasil Belajar & Pertemuan I & Pertemuan II & Jumlah & Rata-rata & Kualifikasi \\
\hline
\end{tabular}

\section{Rekapitulasi Hasil Penilaian Proyek Siklus I}

\begin{tabular}{|c|c|c|c|c|c|}
\hline Hasil Pengamatan & \multicolumn{4}{|c}{ Siklus I } \\
\cline { 2 - 6 } & Pertemuan I & Pertemuan II & Jumlah & Rata-rata & Kualifikasi \\
\hline Hasil Proyek & 64,14 & 74,78 & 138,92 & 69,46 & C \\
\hline
\end{tabular}

\section{Penelitian Siklus II}

Siklus II dilaksanakan pada tanggal 24 Maret 2021 pada pukul $07.30-10.30$ WIB.

1. Perencanaan
a. RPP
b. LKP
c. Lembar Evaluasi
d. Kunci jawaban lembar evaluasi
e. Instrumen Penilaian RPP
f. Lembar Pengamatan Aktivitas Guru
g. Lembar Pengamatan aktivitas Siswa

2. Pelaksanaan

Pelaksanaan pembelajaran pada siklus II pertemuan I dengan model Project Based Learning ( $\mathrm{PjBL}$ ) dilaksanakan dikelas $\mathrm{V}$ SDN 20 Indarung. Pertemuan pertama dilaksanakan pada hari Rabu tanggal 24 Maret pada pukul 07.30 sampai 10.30 WIB. Siswa yang hadir pada pertemuan ini berjumlah 20 orang. Pada saat pelaksanaan, peneliti berperan sebagai praktisi (guru) dan guru kelas $\mathrm{V}$ sebagai observer yang mengamati jalannya pembelajaran tematik terpadu Tema 8 Subtema 3 Pembelajaran 1 dengan model Problem Based Learning (PBL). Pelaksanaan terdiri dari 3 kegiatan meliputi kegiatan pendahuluan, inti, dan penutup.

3. Pelaksanaan
a. RPP
b. Pelaksanaan pembelajaran (Kegiatan guru \& Kegiatan Siswa).

4. Refleksi

Refleksi tindakan siklus II ini mencakup refleksi terhadap perencanaan pembelajaran, pelaksanaan pembelajaran dari aspek guru dan siswa. Dilihat dari hasil paparan siklus II bahwa langkah pembelajaran telah dilaksanakan dengan baik. Pelaksanaan 
pembelajaran dengan model Project Based Learning juga telah berhasil dilaksanakan sesuai dengan waktu yang direncanakan walaupun masih terdapat kekurangan.

\section{Hasil Pengamatan Siklus I dan Siklus II}

Tabel 2. Rekapitulasi Hasil Pengamatan dan Hasil Belajar Siklus I dan Siklus II

\begin{tabular}{|l|c|c|c|c|c|c|c|c|}
\multicolumn{1}{|c|}{ Hasil Pengamatan } & \multicolumn{1}{|c|}{$\begin{array}{c}\text { Pertemua } \\
\text { n I }\end{array}$} & $\begin{array}{c}\text { Pertemua } \\
\text { n II }\end{array}$ & Jumlah & Rata-rata & $\begin{array}{c}\text { Kualifi } \\
\text { kasi }\end{array}$ & $\begin{array}{c}\text { Pertemua } \\
\text { n I }\end{array}$ & $\begin{array}{c}\text { Kualifi } \\
\text { kasi }\end{array}$ \\
\hline $\begin{array}{l}\text { Rencana } \\
\begin{array}{l}\text { Pelaksanaan } \\
\text { Pembelajaran }\end{array}\end{array}$ & RPP & $82,1 \%$ & $85,71 \%$ & $167,81 \%$ & $83,90 \%$ & B & $92,9 \%$ & SB \\
\hline $\begin{array}{l}\text { Pelaksanaan } \\
\text { Pembelajaran }\end{array}$ & $\begin{array}{l}\text { Aspek } \\
\text { Guru }\end{array}$ & $71,9 \%$ & $84,3 \%$ & $156,2 \%$ & $78,1 \%$ & B & $93,8 \%$ & SB \\
\hline & $\begin{array}{l}\text { Aspek } \\
\text { Siswa }\end{array}$ & $71,9 \%$ & $84,3 \%$ & $156,2 \%$ & $78,1 \%$ & B & $93,8 \%$ & SB \\
\hline Hasil Belajar & & 75,56 & 81,37 & 156,93 & 78,46 & B & 85,53 & B \\
\hline
\end{tabular}

\section{Hasil Penilaian Proyek Siklus I dan Siklus II}

Tabel 3. Rekapitulasi Hasil Penilaian Proyek Siklus I dan Siklus II

\begin{tabular}{c|c|c|c|c|c|}
\hline Hasil Pengamatan & Siklus I & Siklus II & Jumlah & Rata-rata & Kualifikasi \\
\hline Hasil Proyek & 69,46 & 83,18 & 152,64 & 76,32 & B \\
\hline
\end{tabular}

Grafik Peningkatan hasil belajar siswa kelas V SD Negeri 20 Indarung menggunakan model Project Based Learning (PjBL).

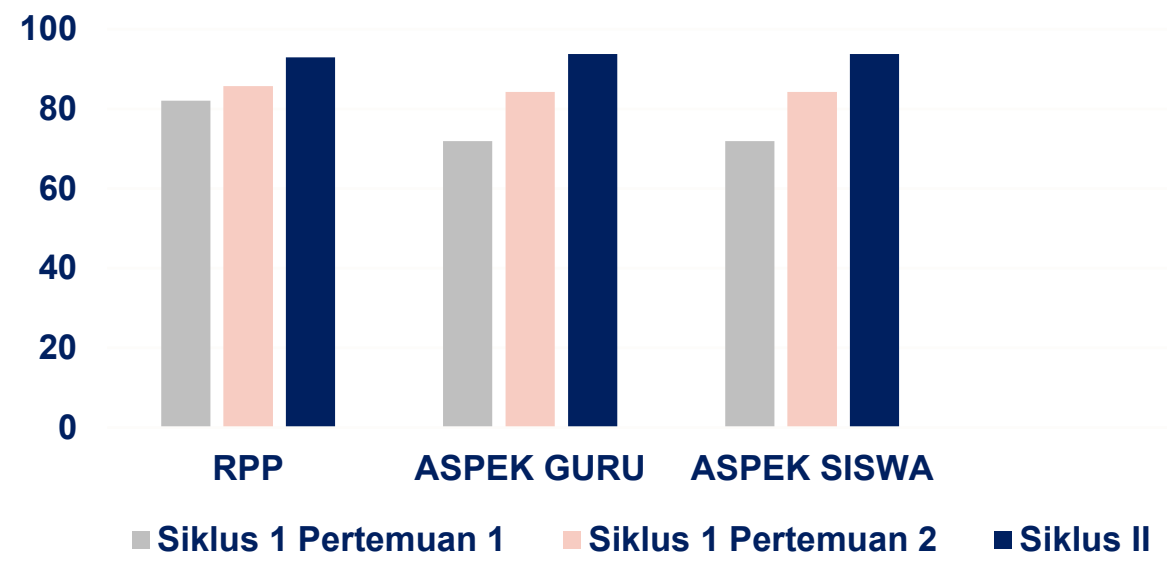




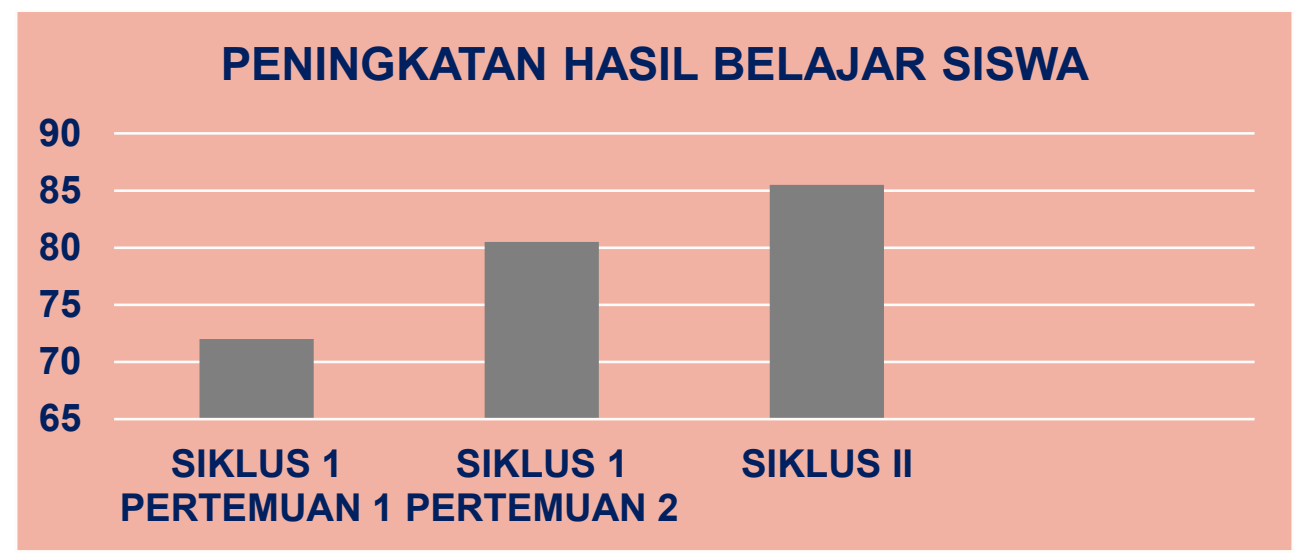

\section{SIMPULAN}

Berdasarkan hasil penelitian, perencanaan pembelajaran, pelaksanaan pembelajaran, dan pembahasan tentang peningkatan hasil belajar siswa pada pembelajaran tematik terpadu Tema 8 dengan menggunakan model Project Based Learning (PjBL) di kelas V SDN 20 Indarung Kota Padang dapat disimpulkan bahwa "Terdapat peningkatan hasil belajar siswa pada pembelajaran tematik terpadu Tema 8 dengan menggunakan model Project Based Learning (PjBL) di kelas V SDN 20 Indarung Kota Padang" Berdasarkan hasil pengamatan RPP, pelaksanaan pembelajaran (aspek guru dan aspek siswa), dan hasil belajar siswa diperoleh $9 \%$ peningkatan rencana pelaksaan pembelajaran, $15,7 \%$ peningkatan pelaksanaan pembelajaran (aspek guru dan aspek siswa), 7,07\% peningkatan hasil belajar siswa, dan $13,72 \%$ peningkatan hasil penilaian proyek di pembelajaran tematik terpadu Tema 8 SD Negeri 20 Indarung Kota Padang.

\section{DAFTAR PUSTAKA}

Basrowi dan Suwandi. 2008. Memahami Penelitian Kualitatif. Jakarta: Rineka Cipta

Daryanto. 2014. Pendekatan Pembelajaran Saintifik Kurikulum 2013. Yogyakarta: Gava Media

Dimyati. 2009. Belajar dan Pembelajaran. Jakarta : PT Rineka Cipta.

Eka Lestari, Karunia, dkk. 2017. Penelitian Pendidikan Matematika. Bandung: PT.Refika Aditama

Hosnan. 2014. Pendekatan Saintifik dan Konstekstual dalam Pembelajaran Abad 21. Bogor: Ghalia Indonesia

Istarani. 2014. 58 Model Pembelajaran Inovatif. Medan: Media Persada

Juni Priansa, Donni. 2017. Pengembangan Strategi dan Model Pembelajaran. Bandung: CV. Pustaka Setia

Kizkapan, Oktay. 2016. The Effect of Project Based Learning on Seventh Grade Students'Academic Achievement. International Journal of Instruction January 2017.Vol.10, No.1e-ISSN: 1308-1470, diakses tanggal 10 Januari 2021 
Kunandar. 2010. Langkah Mudah Penelitian Tindakan Kelas sebagai Pengembangan Profesi Guru. Jakarta :Raja Wali Press.

Majid, Abdul. 2014. Pembelajaran Tematik Terpadu. Bandung : Remaja Rosdakarya.

Maudi, Nadea. 2016. Implementasi Model Project Based Learning Untuk Meningkatkan Kemampuan Komunikasi Matematis Siswa. Jurnal Pendidikan Matematika Indonesia, Vol.1, No.1, p-ISSN: 2477-5967 e-ISSN: 2477-8443, diakses tanggal 10 Januari 2021

Oemar, Hamalik.2008. Proses Belajar Mengajar. Bandung: Bumi Aksara

Purwanto, Ngalim. 2010. Prinsip-prinsip dan Teknik Evaluasi Pengajaran. Bandung: Remaja Rosdakarya.

Sugiyono. 2011. Metode Penelitian Pendidikan. Bandung: Alfabeta

Sudjana, Nana. 2011. Tuntunan Penyusunan Karya IImiah. Jakarta : Sinar Baru.

Sumantri dan Syarif, M. 2015. Strategi Pembelajaran. Jakarta : Rajawali Pers.

Tracy. 2012. Teaching Mathematics in a Project-Based Learning Context: Initial Teacher Knowledge and Perceived Needs. Mathematics Education Research Group of Australasia,diakses tanggal 10 Januari 2021

Trianto. 2014. Mendesain Model Pembelajaran Inovatif, Progresif, dan Konstektual. Jakarta: Prenada Media Group Turgut, Halil. 2008. Prospective Science Teachers' Conceptualizations About Project Based Learning. International Journal of Instruction. Volume I. No. 2. 61-79. http://www.e-iji.net. Diakses tanggal 20 Maret 2021

Uno, Hamzah B, dkk. 2011. Menjadi Peneliti PTK yang Profesianal. Jakarta: Bumi Aksara.

Yamin, Y., Permanasari, A., Redjeki, S., \& Sopandi, W. (2017). Application of Model Project Based Learning on Integrated Science in Water Pollution. Journal of Physics: Conference Series, 895(1). https://doi.org/10.1088/1742-6596/895/1/012153. Diakses tanggal 20 Maret 2021 